\title{
The Potential Role of Drove Roads as Connecting Corridors for Birds between Natura 2000 Sites
}

\author{
Juan E. Malo ${ }^{1,2, *(\mathbb{D})}$ and Cristina Mata ${ }^{1,2}$ (D) \\ 1 Terrestrial Ecology Group (TEG-UAM), Departamento de Ecología, Facultad de Ciencias, \\ Universidad Autónoma de Madrid, C Darwin 2, 28049 Madrid, Spain; cristina.mata@uam.es \\ 2 Centro de Investigación en Biodiversidad y Cambio Global (CIBC-UAM), Universidad Autónoma de Madrid, \\ C Darwin 2, 28049 Madrid, Spain \\ * Correspondence: je.malo@uam.es; Tel.: +34-91497-8012
}

Citation: Malo, J.E.; Mata, C. The Potential Role of Drove Roads as Connecting Corridors for Birds between Natura 2000 Sites. Birds 2021, 2,314-328. https://doi.org/10.3390/ birds2030023

Academic Editor: Jukka Jokimäki

Received: 4 July 2021

Accepted: 8 September 2021

Published: 15 September 2021

Publisher's Note: MDPI stays neutral with regard to jurisdictional claims in published maps and institutional affiliations.

Copyright: (c) 2021 by the authors. Licensee MDPI, Basel, Switzerland. This article is an open access article distributed under the terms and conditions of the Creative Commons Attribution (CC BY) license (https:// creativecommons.org/licenses/by/ $4.0 /)$.
Simple Summary: Drove roads (the traditional paths used to move livestock between villages and among grazing grounds, frequently with some tree cover) have been suggested to be ecological refuges and corridors of interest to complement the European Natura 2000 Network. However, their narrowness cast doubts regarding their capacity to act as connectors for vertebrates with large home ranges, such as birds. Here we show that bird communities in drove roads crossing agrarian landscapes in the Madrid Region (Spain) are a predictable subset of species in comparison to those in wooded protected sites, and that species richness declines in them with the distance from Natura 2000 sites and with the reduction in forest cover of the area. Thus, drove roads sustain nesting bird communities that depend on the wider landscape rather than on their own characteristics, and can only play a secondary role as refuges, stepping stones or corridors funneling bird movements between protected sites.

Abstract: Ecological connectivity among protected Natura 2000 sites is a priority for conservation in Europe due to the increasing pressure on biodiversity from human activities and climate change. Drove roads, the traditional paths used to move livestock through the territory, have been proposed as potential ecological corridors due to their large extent, continuous nature and centennial protection from ploughing and urbanization, which allows the persistence of some tree cover and natural habitats in them. Bird communities were sampled during the reproductive season along 19 drove road transects in agrarian landscapes between Natura 2000 sites, all of them around the conurbation of Madrid (Madrid Region, Spain). Bird community nestedness was assessed by NODF computation followed by significance estimation by aleatorization, and factors explaining species richness and bird abundance were analyzed through General Linear Models fitted with environmental variables measured on official vegetation maps and orthophotos. Bird communities in drove roads were significantly nested, showing high predictability in the order of species loss from better preserved sites to those under stronger environmental pressures. Accordingly, Poisson regression showed bird richness to decrease strongly with distance from the closest Natura 2000 site and to increase with forest cover at the landscape and at the drove road scales. Bird abundance increased strongly with distance from urban areas and motorways, and it was slightly higher in areas with more forest cover and in transects with less bare ground. These results, and the higher relevance detected for landscape scale variables (500 $\mathrm{m}$ around transects) than for those at the drove road (50 m) scale, show that (i) they can only play a secondary role as habitat for nesting birds but (ii) they may add to the Green Infrastructure strategy as facilitators or stepping stones for bird communities if the surrounding landscape is favorable for them.

Keywords: agrarian landscapes; connectivity; fragmentation; green infrastructure; habitat; human impact; metacommunities; nestedness; urban ecology 


\section{Introduction}

Nature conservation in densely populated areas represents a challenge whose success relies on the protection of core conservation areas interconnected either by ecological corridors or by landscapes that keep at least a relevant fraction of biodiversity [1]. Climate changes make the conservation of interconnected areas even more relevant since many species will have to shift their occupation areas to follow the displacement of their optima [2-4]. The European Union is a paradigmatic case in this sense due to its population density, long history of human occupation and extent of cultural landscapes dependent for centuries on human activities [5,6]. In order to achieve its conservation objectives, the EU has thus combined the traditional focus on the conservation of sites through the Natura 2000 network with an increased attention to the connection between them by the 'blue' and 'green' infrastructures [7-9]. Thus, the conservation of rivers and gallery forests is a core objective due to both their condition of habitats under strong human pressure and their potential to connect protected areas thanks to their extent and spatial continuity $[10,11]$. In parallel, the need to provide ecological connectivity to the Natura 2000 Network has been defined as a priority to be faced by either the definition of a network of ecological corridors or the implementation of a conservation-focused management of territories between protected sites $[12,13]$. Therefore, the green infrastructure is seen as the potential instrument to complement the protection of sites by improving the long-term stability of conservation objectives and providing multiple benefits for wildlife, human activities and the population living in towns or the countryside $[7,14,15]$. However, the best procedure to achieve the objectives of ecological networks is under debate since it should rest on a balanced analysis of the specific conservation needs and outcomes provided by interventions on core areas, corridors and the matrix [16,17]. Accordingly, the green infrastructure potentially embraces built areas, gardens and urban parks together with landscapes under agrarian use and ecological corridors cutting across the countryside. However, this approach risks green infrastructure to become a panchreston including too many elements of unknown benefits, as well as to focus on the spatial arrangement of such elements based on their physical presence (contiguity) without formal attention to their actual functionality (connectivity) $[17,18]$.

Drove roads, the paths traditionally used to move livestock between villages and among grazing grounds (Figure 1), have a high potential to fulfill the needs of the green infrastructure $[8,19]$. Three reasons support this point: (i) they are continuous tracks of land cutting across the whole territory; (ii) they reach great lengths and (iii) they may cover a relevant area in many places. For instance, in Spain they span over 125,000 km and cover roughly $1 \%$ of the country [20]. Such lengths and their network nature have called the attention for their potential as ecological corridors [21,22]. Moreover, their condition of public lands preserved for livestock movements precluded ploughing since remote times, thus allowing the maintenance of interesting ecological processes within them. The proposal of drove roads as ecological corridors is mainly grounded in contiguity approaches, but there is some information about their actual functional roles. For instance, traditional movement of herds along them transports seeds and invertebrates between landscape patches spread over large areas, improving connectivity and allowing long distance colonization processes [23-25]. As a drawback, drove roads are in general narrow (15-75 $\mathrm{m}$ in the Spanish case, [26]), and this may hinder their capacity to provide refuge or connectivity to large bodied species with wide home ranges such as many mammals or birds [27]. Moreover, edge effects could predominate in them [18]. 


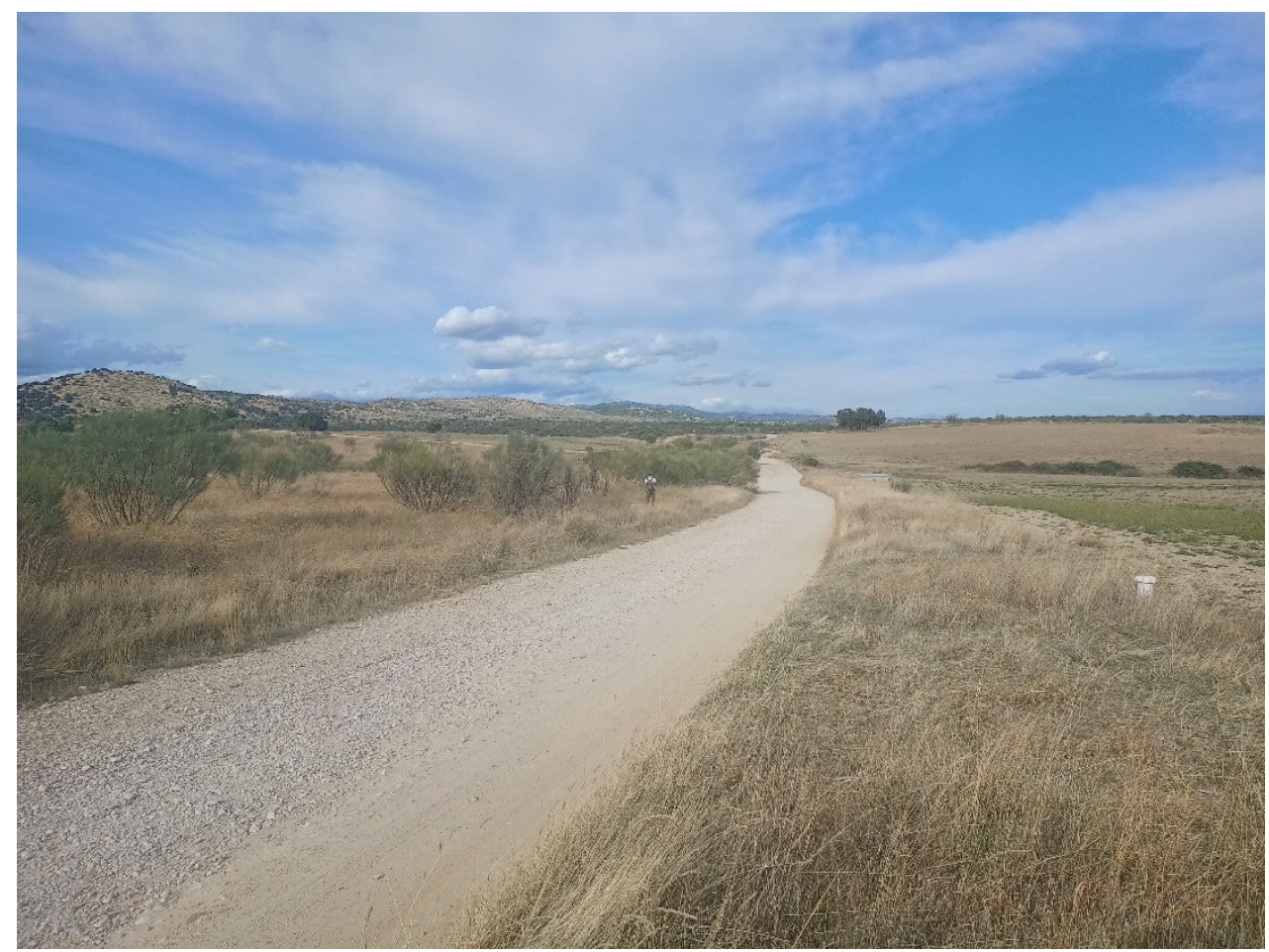

Figure 1. A drove road crossing croplands in Madrid Region. Note the extent of unploughed land and the development in it of permanent grasslands with Retama spaerocarpa shrubs.

Birds are a flagship group for ecological conservation and environmental education due to their high species diversity and the variety of ecological roles they play, as well as for their attractiveness to humans [28,29]. Several species live even in the center of large cities but bird communities lose species and frequently have reduced bird numbers along gradients of human pressure, represented by reductions in tree and shrub cover, homogenization of habitats and edification [30-32]. Thus, bird communities in urban and sub-urban areas include only a fraction of the regional species assemblages or they are combinations of native with non-native species [33,34]. A nested organization of bird communities along gradients of human pressure has been described, where more tolerant species are a predictable subset of those present in species-rich communities of well-preserved sites $[35,36]$. Such sites are frequently forest remnants that harbor less tolerant species and those of more specialized requirements $[37,38]$, though this process is less pronounced in temperate areas [39]. Nest predation has been blamed as a key process underlying this pattern, since it is consistently higher in the agrarian landscapes and in the margins of croplands than inside deep forests of several regions [40,41].

Therefore, bird conservation in densely populated areas depends on the maintenance of natural vegetation remnants but also on the connectivity among them [42-44]. Although flight allows birds to reach distant points, even within the urban matrix, ecological corridors are also useful for them $[31,45,46]$. In the case of agrarian landscapes in the Mediterranean, species richness decreases with the loss of forest cover and with the reduction of available microhabitats [37,47]. Moreover, forest species are substituted by others typical from open ground in croplands, and diversity is largely reduced in areas with more intensified agrarian practices [37]. Distance or isolation from forest patches further reduce bird species richness in remnants $[47,48]$. From this perspective, the areas free of agrarian activity can act as local refuges allowing forest species to nest, and the contribution of drove roads to the green infrastructure will depend on the relative relevance of local and landscape effects, and on the intensity of human pressure suffered by them [11,44]. Additionally, the increased activity of predators in edges of agrarian landscapes could hinder the occupation or reproduction of birds in drove roads [41,49]. 
The main objective of this study is to describe bird communities in drove roads crossing agrarian landscapes and potentially acting as refuges or corridors between Natura 2000 sites of a densely populated region. In short, we (i) analyze whether bird communities in the reproductive season change abruptly in the drove roads crossing agrarian areas or if they just show a reduction in species richness associated with human pressures. In the latter case, we would predict bird communities in drove roads crossing areas under stronger human pressure to be a predictable (nested) subset of those present under lower pressure. Agrarian landscapes would thus represent mid-resistance surfaces (the fewer the species loss, the lower the resistance) for the connectivity between conservation areas, while a total substitution of species could be interpreted as the presence of a strong barrier between them. Moreover, we (ii) aim to know whether birds respond mainly to the small-scale habitat structure provided by drove roads, thus acting as bird reproductive refuges, or if bird presence is more related to the wider landscape (the matrix), be it in the form of habitat configuration or of distances to protected sites or perturbation sources. In this second case, the role of drove roads for bird conservation would be minor, and it would be related to some capacity to improve connectivity between protected sites.

\section{Methods}

\subsection{Study Area and Sampling}

The study was conducted in 19 sections of main drove roads connecting Natura 2000 sites in Madrid Region, Central Spain (Figure 2). All sampling sections were located on gently undulating landscapes developed on Tertiary sands. Altitude ranges between $580-780 \mathrm{~m}$ asl and climate is Mediterranean with a dry summer lasting from June to September. Holm oak (Quercus rotundifolia) forests covered the area in ancient times but most of it has been cultivated for centuries, and it now keeps a mosaic of dry crops, terophite grasslands, tall Retama sphaerocarpa scrubs, low scrubs (Lavandula stoechas, Thymus spp.) and forest patches dominated by Holm oak and Juniperus oxycedrus. Due to scarce and irregular rains, and the permeability of substrata, most creeks carry water only in autumn and winter, and they support dense Rubus spp. and Rosa spp. scrubs. Permanent rivers have forest belts dominated by Salix spp., Populus spp., Alnus glutinosa and Fraxinus angustifolia.

The area embraces by the North and West the conurbation of Madrid (a total of ca. 5.5 million inhabitants, with densities of 200-2000 inhabitants by square kilometer in most counties), but towns are in general compact and they leave large tracts of agrarian landscapes in between. The sampled drove roads are located between Natura 2000 sites ES3110001 (Cuencas de los Ríos Jarama y Henares), ES3110003 (Cuenca del río Guadalix), ES3110004 (Cuenca del Río Manzanares), ES3110005 (Cuenca del Río Guadarrama) and ES3110007 (Cuencas de los ríos Alberche y Cofio). These protected areas maintain large patches of forest and they follow the larger rivers in the Region, with a North-South direction. Between Natura 2000 sites, tracts of land 5-15 km wide are covered by a mixture of crops, grasslands, forests and some scattered human activities (industrial, residential, sport facilities, etc.). Drove roads cross these landscapes and frequently sustain more tree, scrub and permanent grassland cover than their immediate surroundings. They have an unpaved track in the middle (4-6 $\mathrm{m}$ width), but transit of motorized vehicles is restricted in them to agrarian machinery, access to farms and patrolling activities, while their use is free for bikes and pedestrians. Transects were carried out in drove road sections at distances between 0 and $7098 \mathrm{~m}$ from the nearest Natura 2000 site. 


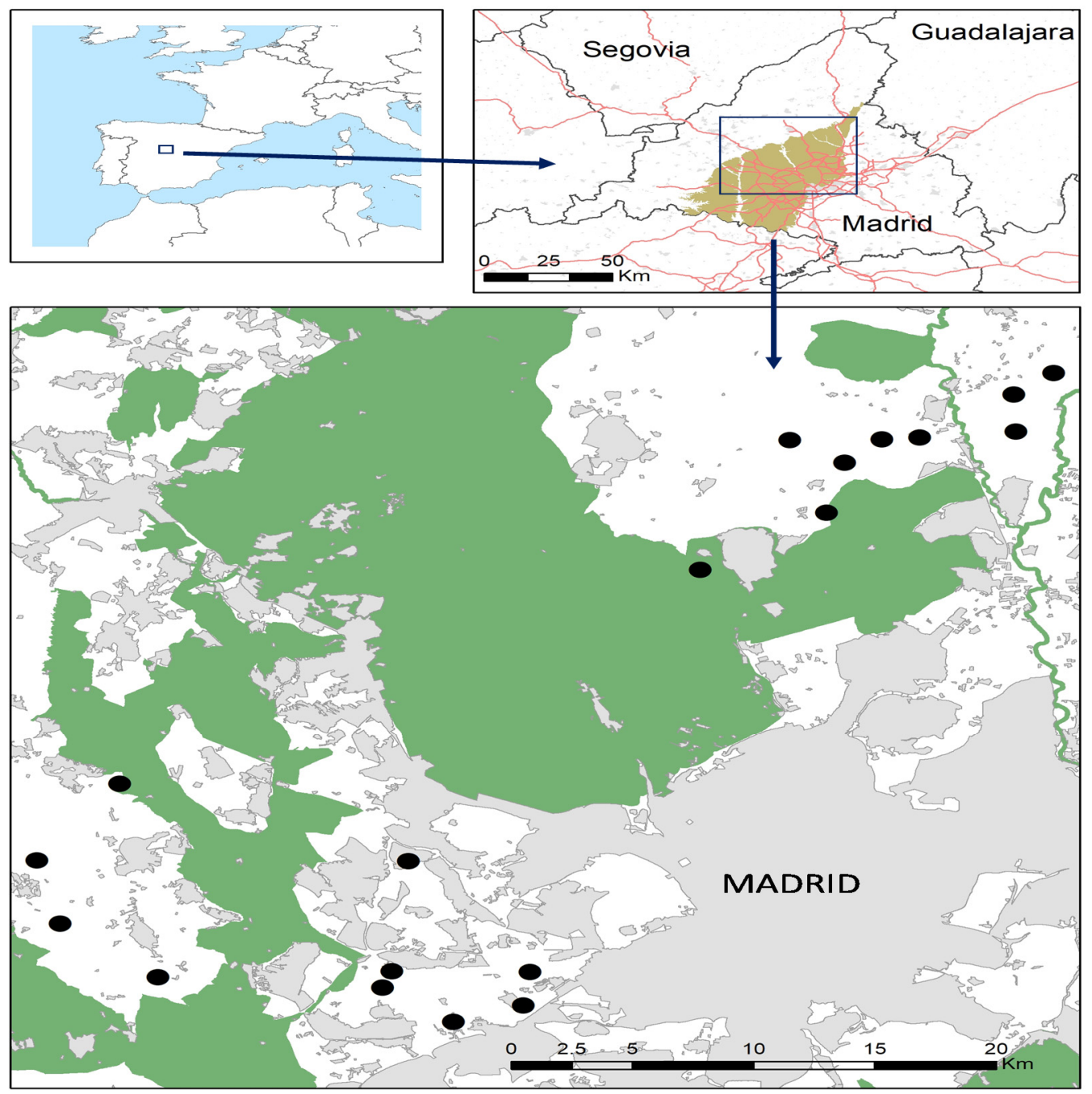

Figure 2. Study area: general location maps (above) and local situation of transects (black dots) around Madrid (below). In the latter figure, Natura 2000 sites are depicted in green and grey areas correspond with urban areas (Madrid city and its conurbation).

Sampling was performed in a $1000 \mathrm{~m}$ line transect of each drove road section, with a minimum distance of $519 \mathrm{~m}$ between them. Bird sampling was carried out in spring 2020 by walking through the center of the drove road (21-75 $\mathrm{m}$ wide) and taking note of birds heard or seen in a $25 \mathrm{~m}$ band at each side of the observer [50]. Birds seen crossing the transect in flight were also noted to have a complementary record of large birds and for those species (e.g., swallows and swifts) that spend most of the time flying, sampling was performed by one observer walking at ca. $2 \mathrm{~km} / \mathrm{h}$ with $10 \times 42$ binoculars and a laser rangefinder (Leica Rangefinder 1200) used to avoid the inclusion of observations outside the sampling band but close to it [50]. Each transect was sampled once along the spring, always within the first three hours of the morning in days without rain or strong wind.

We used a geographic information system (GIS) to extract potential explanatory variables of three types (Table 1): (i) ground cover at a local scale (drove road scale hereafter), defined using a $50 \mathrm{~m}$ buffer around the transect line; (ii) ground cover at the landscape scale (500 $\mathrm{m}$ buffer around transect line) [51] and (iii) distance of transects to forest, to protected areas and to main sources of human perturbation. At the local scale we distinguished eight land cover types: bare ground, urban, crops, grassland, low open scrub, Retama sphaerocarpa scrub, riparian vegetation and Holm oak forest. Percentage cover of each type was estimated visually on $25 \mathrm{~cm}$-resolution digital orthophotos accessible online [52] and corroborated by fieldwork. The same land cover types (with urban and 
bare ground lumped together) were extracted from the 1:50,000 vegetation map published by Madrid Region [53]. The distances from each transect to the nearest Natura 2000 site, to the closest urban area or motorway and to the nearest forest patch larger than $5 \mathrm{Ha}$ were also calculated with ArcGIS 10.7.1 [54].

Table 1. Variables tested in explicative models of bird richness and abundance in transects carried out in drove roads. Variables are organized in the three potential explanatory sets used for initial models, and descriptive values for sampled transects included for informative purposes.

\begin{tabular}{cc}
\hline Variables & Mean \pm SD [Max.-Min.] \\
\hline Ground cover at the drove road (50 m buffer) scale \\
Bare ground (\%) & $7.52 \pm 4.55[0-16.0]$ \\
Urban (\%) & $1.00 \pm 1.97[0-6.4]$ \\
Crops (\%) & $26.50 \pm 31.47[0-86.9]$ \\
Grassland (\%) & $40.41 \pm 31.35[0-89.3]$ \\
Low open scrub (\%) & $1.64 \pm 2.71[0-6.9]$ \\
Retama sphaerocarpa scrub (\%) & $16.79 \pm 24.84[0-79.0]$ \\
Riparian vegetation (\%) & $1.24 \pm 2.99[0-12.0]$ \\
Holm oak forest (\%) & $5.14 \pm 9.73[0-34.8]$ \\
Ground cover at the landscape (500 m buffer) & scale \\
Urban and bare ground (\%) & $8.44 \pm 17.39[0-69.5]$ \\
Crops (\%) & $34.22 \pm 33.58[0-86.3]$ \\
Grassland (\%) & $10.76 \pm 15.68[0-53.3]$ \\
Low open scrub (\%) & $0.94 \pm 2.16[0-8.1]$ \\
Retama sphaerocarpa scrub (\%) & $20.35 \pm 20.43[0-62.0]$ \\
Riparian vegetation (\%) & $1.99 \pm 2.25[0-7.2]$ \\
Holm oak forest (\%) $\quad$ Location of the transect & $23.29 \pm 33.36[0-96.6]$ \\
Distance (m) to the nearest Natura 2000 site & $2254.2 \pm 2044.0[0-7098]$ \\
Distance $(m)$ to the closest urban area or high capacity roads & $734.3 \pm 570.4[35.3-2052]$ \\
Distance $(m)$ to the nearest forest patch larger than 5 Ha & $486.7 \pm 602.9[0-2391]$ \\
\hline
\end{tabular}

\subsection{Data Analyses}

In order to know if bird communities show a predictable structure linked to a conservation-degradation gradient [35], 'nestedness' was analyzed with $\mathrm{NeD}$ software [55]. Nestedness appears when the species composition of small assemblages are nested subsets of larger ones, a pattern produced if disturbance triggers an ordered sequence of species absences along a disturbance gradient due to distinct interspecific susceptibilities to it [56]. To test for the significance of the pattern observed in an experimental case, nestedness analyses use a standard index computed from the observed data and the randomization of the original matrix of presences and absences to obtain a probability estimation for the observed value of the index. NODF (Nestedness index based on Overlap and Decreasing Fills) [56] was used in our case to measure nestedness but other indexes of common use (Matrix Temperature -MT-, Brualdi and Sanderson Discrepancy -BR-) showed similar results. The probability associated with the NODF value obtained was assessed by 999 permutations with proportional column and row totals, and the optimally packaged matrix is presented as a visual aid for interpretation.

In parallel, we analyzed if bird richness or abundance in transects is associated with the three types of explanatory variables presented above. For each response variable we first built a model with explanatory variables of only one type, selecting the best model according to its AIC value. In a second step we built a final model with variables of the three types by the same procedure, though allowing only the inclusion of variables selected in the first step.

Poisson regressions were used for models of species richness by transect, and linear models were fit to abundance data (log-transformed to reduce the weight of bird flocks). Prior to model building, we checked that the only variables strongly correlated between them $(|r>0.7|)$ were the cover of grasslands and the cover of crops at the drove road 
scale, which are complementary $(r=-0.734)$ and therefore they were not tested together. McFadden pseudo-r ${ }^{2}\left(R^{2}\right)$ of models is used to inform about relative fit [57], and for final models we present the basic statistics of parameters included in them corrected for overdispersion. Model residuals were checked visually on P-P and predictions vs. residuals plots.

Finally, for the whole set of species, and species-by-species for those present in more than $50 \%$ of transects, we checked for the correlation between abundance and species richness of the transect. This was tested by Pearson correlations between species richness in transects and the number of birds of each abundant species (or the total). As above, bird abundances were log-transformed prior to analysis.

Linear models and correlation analyses were carried out with Statistica 8.0 [58] with the significance threshold fixed at $p<0.05$.

\section{Results}

A total of 36 species were detected within transects (mean \pm SD $8.3 \pm 3.4$ species/ transect), with an estimated density of 705 birds /100 Ha (Table S1). House Sparrow (Passer domesticus), Eurasian Magpie (Pica pica), Crested Lark (Galerida cristata), Spotless Starling (Sturnus unicolor) and European Serin (Serinus serinus) were detected in more than 50\% of the transects, and four more species with $32-42 \%$ presences: Common Wood Pigeon (Columba palumbus), European Goldfinch (Carduelis carduelis), Sardinian Warbler (Curruca melanocephala) and Eurasian Blue Tit (Cyanistes caeruleus). Moreover, 15 species were only detected in flight over transects, including 7 raptors: Cinereous Vulture (Aegypius monachus), Red and Black Kites (Milvus milvus and M. migrans) and Booted Eagle (Hieraaetus pennatus). Other species commonly detected flying over the transects were Common Swift (Apus apus), Common Wood Pigeon (Columba palumbus), Barn Swallow (Hirundo rustica) and Western Cattle Egret (Bubulcus ibis) (Table S1).

Bird communities in drove roads showed a significantly nested structure (observed $\mathrm{NODF}=41.58 ; \mathrm{Z}=7.13 ; p<0.001$ ) so that the arrangement of transects by decreasing richness makes evident both a progressive drop of bird species and the presence of a core of common species in most transects (Table 2).

Explanatory models of species richness built with variables at the drove road scale (McFadden $R^{2}=0.36$ ) and with distances (McFadden $R^{2}=0.35$ ) showed similarly good fit, with two predictor variables in each case: Holm oak cover and urban in the former, and distances to Natura 2000 and to forest patch in the latter. The model built with landscape scale variables showed a poorer fit $\left(\right.$ McFadden $\left.R^{2}=0.25\right)$ and it included the variables forest cover and riparian vegetation cover. The final model showed a much better fit (McFadden $R^{2}=0.55$ ), and it included one variable from each original set (Table 3). According to this model, bird richness in transects decreases with the distance from the closest Natura 2000 site, increases with forest cover in the $500 \mathrm{~m}$ surrounding it and also (marginally, non-significant) with the cover of Holm oaks present in the drove road.

The explanatory model of bird abundance in drove roads based on distances was the most powerful one in the first modeling step (McFadden $R^{2}=0.46$ ), and it included only the variable distance to a source of human perturbation (town or motorway). It was followed with a lower explanatory power by the model of variables at the drove road scale (McFadden $R^{2}=0.25$ ) that included the cover of bare ground and that of Retama sphaerocarpa scrubs. The model built with variables at the landscape scale was less informative (McFadden $R^{2}=0.15$ ) and it included only the forest cover. Accordingly, the final model (McFadden $R^{2}=0.57$ ) included the variables' distance to human perturbation, bare ground cover at the drove road scale and forest cover at the landscape scale (Table 4). The parameters of the model show that bird abundance increases with the distance from areas with strong human perturbation. A (marginal) tendency was found for a reduction in bird abundance in transects with more bare ground, and also for a (non-significant) increase with the cover of forests at the landscape scale. 
Table 2. Nested structure of bird communities sampled in drove roads. Bird species (rows) and transects (columns) are organized to show species presences (gray squares) optimally packed close to the upper-left corner. Species richness of each transect is shown under the 'nestedness diagram'.

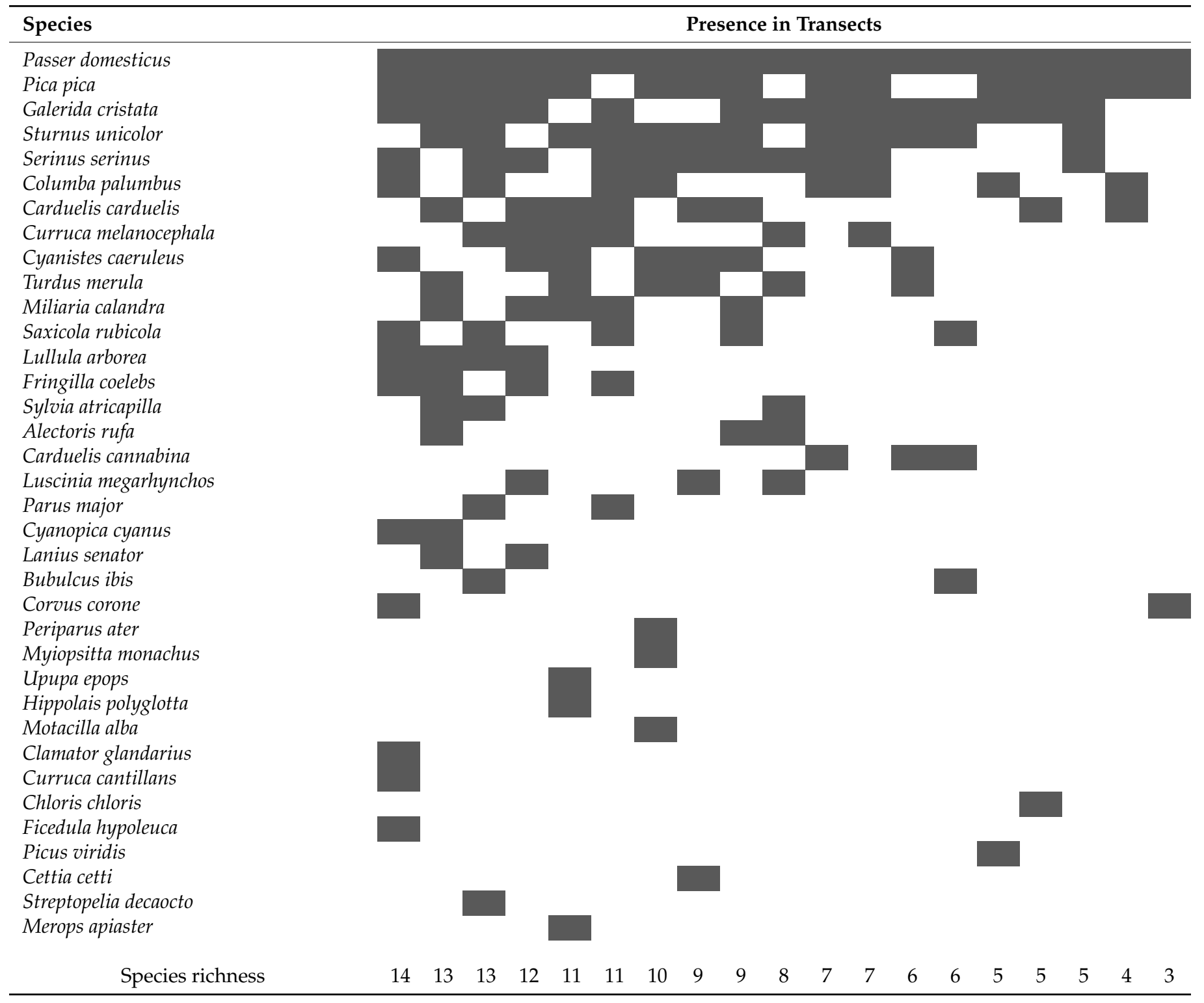

Table 3. Results of the best Poisson regression model explaining bird species richness in drove roads as a function of variables at the landscape and drove road scales.

\begin{tabular}{cccc}
\hline Variables & Estimate \pm SD & Wald Statistic & $p$ \\
\hline Intercept & $2.13965 \pm 0.11220$ & 363.63 & $<0.0001$ \\
Distance to Natura 2000 site & $-0.00012 \pm 0.00004$ & 8.20 & 0.0042 \\
Forest cover $(500 \mathrm{~m})$ & $0.00560 \pm 0.00224$ & 6.23 & 0.0126 \\
Holm oak forest $(50 \mathrm{~m})$ & $0.01254 \pm 0.00683$ & 3.37 & 0.0665 \\
\hline
\end{tabular}


Table 4. Results of the best linear regression model explaining bird abundance (log-transformed) in drove roads as a function of variables at the landscape and drove road scales.

\begin{tabular}{cccc}
\hline Variables & Estimate \pm SD & Wald Statistic & $p$ \\
\hline Intercept & $1.33285 \pm 0.09783$ & 185.62 & $<0.0001$ \\
Distance to urban areas & $0.00026 \pm 0.00007$ & 13.00 & 0.0003 \\
Forest cover $(500 \mathrm{~m})$ & $0.00200 \pm 0.00123$ & 2.62 & 0.1057 \\
Bare ground $(50 \mathrm{~m})$ & $-0.01580 \pm 0.00883$ & 3.20 & 0.0738 \\
\hline
\end{tabular}

Bird abundance and richness in transects was correlated only marginally $(r=0.397$; $n=19 ; p=0.092)$ and among the five more frequent species the abundance of House Sparrow was higher in transects with fewer species $(r=-0.468 ; p=0.046)$. On the contrary, correlations for all other species were absent $(|r|<0.23$ with $p>0.347$ in all cases) with both cases where the tendency was negative (Eurasian Magpie and European Serin) and positive (Eurasian Skylark and Spotless Starling).

\section{Discussion}

Our results show that drove roads crossing agrarian landscapes in a densely populated region have bird communities impoverished in comparison to those closer to protected areas with oak forests, but that they maintain a fraction of the original species assemblage in them. Moreover, bird species richness in drove roads decreases with distance from Natura 2000 sites and in areas with less tree cover, suggesting that drove roads in these landscapes may play only a minor role as refuges for birds though they could somewhat improve connectivity between protected areas dominated by woods.

Bird communities in the drove roads of the agrarian and peri-urban study area surrounding Madrid are not characterized by a sharp substitution of forest species by anthropophiles, but they show a progressive (nested) loss of the less tolerant species linked to gradients of human pressure $[30,35]$. In this way, they can be interpreted as part of a bird meta-community occupying the whole area $[59,60]$ as they can participate in the balance of processes (reproduction, mortality, dispersal) that lead to the temporal occupation or disappearance of species from different landscape patches [61,62]. Thus, drove roads in the area provides a habitat for the reproduction of several species, even though the core of the assemblage is composed of synanthropic species such as the House Sparrow and Eurasian Magpie and specialist species are underrepresented among them [63]. In fact, some forest specialists present in forest patches of the area (e.g., Long-tailed tit-Aegithalos caudatus-, Short-toed Treecreeper-Certhia brachydactyla-, Great Spotted Woodpecker-Dendrocopos major- [64]) were not detected during sampling, and probably only wandering individuals in autumn and winter use drove roads. In the case of more tolerant species, they could be subordinate individuals with a lower reproductive success than those occupying core protected areas acting as sources for colonizers [65].

Additionally, drove roads provide feeding grounds for several species of concern such as the Cinereous Vulture and Red Kite, classified as near threatened at global and European scales [66]. Apart from these species directly seen flying over the drove roads during sampling, the globally vulnerable Spanish Imperial Eagle (Aquila adalberti) [67] was observed twice during fieldwork flying and resting on a treetop around the sampled transects. From the perspective of raptors, it is noticeable that drove roads harbor rabbit (Oryctolagus cuniculus) populations denser than the surroundings, probably as a result of the stability of soil and vegetation in them [68]. A relevant issue regarding any benefit of drove roads for biodiversity is that their status of conservation is linked to their ancient agrarian use and public property, and their management for moving livestock (no tilling, vehicle exclusion, etc.) is also positive for birds, which means that they can be seen as an efficient (cost-free in fact) support to conservation objectives thanks to multifunctionality $[12,14,16]$.

Species loss runs in parallel to a minor reduction in total bird abundance in drove roads, though these processes are not tightly linked and bird abundance in our case is driven by urban pressure more than by habitat modification. Thus, the correlation between 
species richness and abundance is very weak (marginally significant) as a byproduct of differential responses among species. The only relevant case detected is a compensatory increase in House Sparrow abundance in transects with fewer species. This is a remarkable case since it is the core species of the bird communities in drove roads and it was detected in all transects, while its decline has been reported in large areas of North-western Europe under urban pressure $[69,70]$. Probably, the agrarian landscapes in the study area still maintain a combination of foraging grounds, refuges and nesting sites in small constructions favorable for the House Sparrow, and the kind of agrarian practices positive for their populations [71,72]. According to the final model, total bird abundance in drove roads is related to distance from towns and motorways $[44,73]$ and not or very weakly to the habitat characteristics that drive their species richness (see below). Noise could underly these results, since it is a pervasive perturbation in the proximity to human settlements and roads, and it has been blamed as a major stressor of birds [74-76]. However, noise effects may differ among species and observed changes in bird communities close to human infrastructure may be the result of a combination of several pressures and cascading effects deserving further analysis $[77,78]$.

Therefore, drove roads may have some interest as refuges for birds, though mainly related to the habitat characteristics of the surrounding matrix and only secondarily to habitats provided by the drove road itself. This is evidenced by the two variables significantly explaining bird species richness, namely forest cover at the $500 \mathrm{~m}$ scale and distance to the nearest Natura 2000 site. The leading role of forest cover can be interpreted in terms of the anthropic nature of these cultural landscapes whose original forest and scrub cover was cleared in ancient times to leave place for crops and sheep grazing [79]. Accordingly with this origin, forest remnants in the area are the main reservoirs for bird communities and drove roads close to them keep the most species-rich assemblages [37,80,81]. It is important to note here that the agrarian areas sampled here differ from those present in the Iberian Peninsula (even in other areas in Madrid) that maintain bird communities of high conservation relevance [82] with populations of Bustards (Otis tarda, Tetrax terax), Sandgrouses (Pterocles alchata, P. orientalis) or Harriers (Circus pygargus C. cyaneus) typically form steppe-like habitats. The role of drove roads present in these areas would deserve attention, since the presence of stable habitat patches in them is good for several steppe birds [37], but it could promote the presence or activity of nest predators [49].

The two variables at the drove road scale included in the final models (cover of Holm oak forest and of bare ground) fit with a general relevance of forest cover for birds in the area and inform about a minor additional role of the habitat provided for them by the drove road itself. The presence of some Holm oak cover in drove roads promotes bird species richness and bare ground cover is related to lower bird abundance, but the effect of both variables in final models is only marginal. Such a limited relevance in comparison with variables of the wider landscape is not surprising taking into account the linear and narrow structure of these habitats (20-100 m width [20]) and the fact that birds usually respond to landscape structure at scales of hundreds of meters $[10,44,51]$.

In any case, the distance to the nearest Natura 2000 site is the variable with the strongest explanatory power of bird species richness in the drove roads of the study area. This fact depicts a situation where the wooded protected areas function as core areas for bird communities, and agrarian landscapes around them are buffer areas that support bird communities progressively impoverished with distance [44,47]. In such a context, the agrarian landscapes and drove roads between Natura 2000 sites probably play a complementary role in the spatial mosaic of bird communities whose diversity reflects the spatial configuration of forest and open patches [83]. Such complementarity increases the stability of whole communities by smoothing changes in the populations of more generalist species $[62,84]$, as suboptimal sites provide some nesting habitats to receive individuals dispersing from core areas, but they can also provide on other occasions individuals to reinforce or recolonize the core areas [85]. In this context, the better preserved (or restored) 
the forest fragments remaining along the drove roads, the larger the complementary service for the protected areas they can play.

From an ecological connectivity perspective, drove roads could be envisioned as preferential throughways for birds between protected sites due to their capacity to reduce the resistance of open agrarian landscapes for forest birds [22,86]. Public management of drove roads with limitations of use may help this process in three ways. Firstly, drove roads are continuous stretches of land between protected sites and harbor part of the bird community as evidenced in this study. Secondly, the absence of intensive agrarian practices in them (clearing, ploughing, use of chemicals) and public management give them more stability compared with their surroundings, thus favoring birds [37,87]. Finally, drove roads also include 5-60 Ha resting areas and watering points along their way that could act as stepping stones if properly managed and/or restored [21]. In any case, these drove roads in densely populated areas suffer strong human pressure that also needs attention [21,88]. Rubble dumping is common among such activities, and leisure activities span all the range of potential impacts from hiking and mountain bike riding to illegal off-road vehicle driving $[89,90]$. Thus, management should pay attention to all these potential activities in order to be successful while it must give priority to its prescribed main use, namely the transit of livestock between grazing grounds [21,26]. From this perspective, throughout afforestation of drove roads is not an optimal solution since it would reduce the grass offer to moving animals and affect plant and arthropod communities [20]. However, scattered planting of holm oaks (to reach less than $30 \%$ cover, Table 1) or the protection of natural regeneration could provide some shade to herds as well as nesting sites for birds. This action could be of negligible cost, probably beneficial for livestock and it would improve their value for birds as shown here for the reproductive season, while having minimum impacts on soil and arthropods if carried out without heavy machinery.

This study informs about the actual role of drove roads providing habitat for birds during the breeding season in a densely populated agrarian region, though it has several limitations which should be taken into account for future research and potential application. Regarding the dataset, it is restricted to a single visit in one year and it may therefore be incomplete and does not attend to interannual variability. Additionally, species presence and abundance should be complemented with data on their reproductive parameters in order to attain a better picture of the functional role of drove roads in the bird communities of the area. Finally, even though a couple of sampling sites were located within or beside Natura 2000 sites, all comparisons here are restricted to birds sampled in drove roads, without a supplementary set of transects across forests free of tracks which would set the appropriate baseline for bird communities in well preserved sites of the region. These points, together with the study of bird communities in winter and during migration, could form the basis for a comprehensive analysis of the conservation value of drove roads for birds, useful to decide the best conservation actions to be taken for biodiversity in them attending to their primary role as transport infrastructures for livestock and shepherds.

In conclusion, drove roads can play some role in bird conservation but more as potential connectors between Natura 2000 sites than as refuges and habitats for birds due to the small amount of habitat provided by them. Thus, it is important to note that it is the wider landscape crossed by drove roads that allows the partial maintenance of bird communities, and that the whole agrarian matrix must keep some permeability for them. Under this situation, drove roads could work as backbones for the green infrastructure connecting Natura 2000 sites in densely populated areas by providing some extra habitat for nesting birds, and by giving some continuity across the agrarian landscape to the more stable wooded areas under formal protection.

Supplementary Materials: The following are available online at https://www.mdpi.com/article/10 .3390 /birds2030023/s1, Table S1: Abundance (mean \pm SD) of bird species recorded during drove road sampling. 
Author Contributions: J.E.M. and C.M. contributed equally to conceptualization, methodology design and formal analysis; field data acquisition was performed by J.E.M. and GIS analyses by C.M.; writing was led by J.E.M. and draft reviews and editing by C.M. and J.E.M. All authors have read and agreed to the published version of the manuscript.

Funding: This study is derived from research carried out on the role and potential for restoration of drove roads as biodiversity refuges and ecological connectors between Natura 2000 sites, funded by the project EU LIFE Cañadas (LIFE 18 NAT/ES/000930) The Comunidad de Madrid supports the research group through the REMEDINAL TE-CM Research Network (P2018/EMT4338).

Institutional Review Board Statement: Not applicable.

Informed Consent Statement: Not applicable.

Data Availability Statement: The data can be obtained on request from the corresponding author.

Acknowledgments: To all colleagues from the LIFE Cañadas project who helped us with administrative and budgetary issues associated with this work. The Dirección General de Agricultura, Ganadería y Alimentación (Consejería de Medio Ambiente, Ordenación del Territorio y Sostenibilidad, Comunidad de Madrid) provided permission to work in drove roads, and comments from four anonymous referees improved a previous version of the manuscript.

Conflicts of Interest: The authors declare no conflict of interest.

\section{References}

1. Crooks, K.R.; Sanjayan, M. Conenctivity conservation: Maintaining connections for nature. In Connectivity Conservation; Crooks, K.R., Sanjayan, M., Eds.; Cambridge University Press: Cambridge, UK, 2006; pp. 1-19.

2. Thomas, C.D. Climate, climate change and range boundaries. Divers. Distrib. 2010, 16, 488-495. [CrossRef]

3. Araújo, M.B.; Alagador, D.; Cabeza, M.; Nogués-Bravo, D.; Thuiller, W. Climate change threatens European conservation areas. Ecol. Lett. 2011, 14, 484-492. [CrossRef]

4. Mingarro, M.; Lobo, J. Connecting protected areas in the Iberian peninsula to facilitate climate change tracking. Environ. Conserv. 2021, 1-10. [CrossRef]

5. Jongman, R.H.G. Nature conservation planning in Europe: Developing ecological networks. Landsc. Urban Plan. 1995, 32, 169-183. [CrossRef]

6. Agnoletti, M. Rural landscape, nature conservation and culture: Some notes on research trends and management approaches from a (southern) European perspective. Landsc. Urban Plan. 2014, 126, 66-73. [CrossRef]

7. Garmendia, E.; Apostolopoulou, E.; Adams, W.M.; Bormpoudakis, D. Biodiversity and Green Infrastructure in Europe: Boundary object or ecological trap? Land Use Policy 2016, 56, 315-319. [CrossRef]

8. European Commission. Guidance on a Strategic Framework for Further Supporting the Deployment of EU-Level Green and Blue Infrastructure; European Commission: Brussel, Belgium, 2019; p. 101. Available online: https://ec.europa.eu/environment/ nature/ecosystems/pdf/SWD_2019_193_F1_STAFF_WORKING_PAPER_EN_V4_P1_1024680.PDF (accessed on 9 September 2021).

9. Hermoso, V.; Morán-Ordóñez, A.; Lanzas, M.; Brotons, L. Designing a network of green infrastructure for the EU. Landsc. Urban Plan. 2020, 196, 103732. [CrossRef]

10. Oneal, A.S.; Rotenberry, J.T. Scale-dependent habitat relations of birds in riparian corridors in an urbanizing landscape. Landsc. Urban Plan. 2009, 92, 264-275. [CrossRef]

11. de la Fuente, B.; Mateo-Sánchez, M.C.; Rodríguez, G.; Gastón, A.; de Ayala, R.P.; Colomina-Pérez, D.; Melero, M.; Saura, S. Natura 2000 sites, public forests and riparian corridors: The connectivity backbone of forest green infrastructure. Land Use Policy 2018, 75, 429-441. [CrossRef]

12. European Commission. Building a Green Infrastructure for Europe; Publications Office of the European Union: Luxembourg, 2013; p. 24. [CrossRef]

13. European Commission. LIFE and Climate Change Mitigation; Publications Office of the European Union: Luxembourg, $2015 ;$ p. 92. [CrossRef]

14. Snäll, T.; Lehtomäki, J.; Arponen, A.; Elith, J.; Moilanen, A. Green infrastructure design based on spatial conservation prioritization and modeling of biodiversity features and ecosystem services. Environ. Manag. 2016, 57, 251-256. [CrossRef] [PubMed]

15. Chatzimentor, A.; Apostolopoulou, E.; Mazaris, A.D. A review of green infrastructure research in Europe: Challenges and opportunities. Landsc. Urban Plan. 2020, 198, 103775. [CrossRef]

16. Gippoliti, S.; Battisti, C. More cool than tool: Equivoques, conceptual traps and weaknesses of ecological networks in environmental planning and conservation. Land Use Policy 2017, 68, 686-691. [CrossRef]

17. Foltête, J.-C. How ecological networks could benefit from landscape graphs: A response to the paper by Spartaco Gippoliti and Corrado Battisti. Land Use Policy 2019, 80, 391-394. [CrossRef] 
18. Bennet, A.F. Linkages in the Landscape: The Role of Corridors and Connectivity in Wildlife Conservation, 2nd ed.; IUCN: Gland, Switzerland, 2003.

19. Hevia, V.; Azcárate, F.M.; Oteros-Rozas, E.; González, J.A. Exploring the role of transhumance drove roads on the conservation of ant diversity in Mediterranean agroecosystems. Biodivers. Conserv. 2013, 22, 2567-2581. [CrossRef]

20. Azcárate, F.M.; Robleño, I.; Seoane, J.; Manzano, P.; Peco, B. Drove roads as local biodiversity reservoirs: Effects on landscape pattern and plant communities in a Mediterranean region. Appl. Veg. Sci. 2013, 16, 480-490. [CrossRef]

21. Bunce, R.; Aranzabal, I.D.; Schmitz, M.; Pineda, F. A Review of the Role of Drove Roads (Cañadas) as Ecological Corridors; Alterrarapport 1428: Wageningen, The Netherlands, 2006. Available online: http://content.alterra.wur.nl/Webdocs/PDFFiles/ Alterrarapporten/AlterraRapport1428.pdf (accessed on 9 September 2021).

22. Hilty, J.; Worboys, G.L.; Keeley, A.; Woodley, S.; Lausche, B.; Locke, H.; Carr, M.; Pulsford, I.; Pittock, J.; White, J.W.; et al. Guidelines for conserving connectivity through ecological networks and corridors. In Best Practice Protected Area Guidelines Series No. 30; IUCN: Gland, Switzerland, 2020; p. 30. [CrossRef]

23. Fischer, S.; Poschlod, P.; Beinlich, B. Experimental studies on the dispersal of plants and animals on sheep in calcareous grasslands. J. Appl. Ecol. 1996, 33, 1206-1222. [CrossRef]

24. Baonza, J. Poblaciones de Halimium ocymoides disyuntas de su principal área de distribución madrileña: ¿un caso de zoocoria dirigida por las cañadas? Ecología 2000, 14, 151-157.

25. Manzano, P.; Malo, J.E. Extreme long-distance seed dispersal via sheep. Front. Ecol. Environ. 2006, 4, 244-248. [CrossRef]

26. Ley 3/1995. Ley de Vías Pecuarias (Drove Roads Act). 1995. Available online: www.boe.es/buscar/doc.php?id=BOE-A-1995-7241 (accessed on 9 May 2021).

27. Sanderson, J.; Da Fonseca, G.A.B.; Galindo-Leal, C.; Alger, K.; Inchausty, V.H.; Morrison, K.; Rylands, A. Escaping the minimalist trap: Design and implementation of large- scale biodiversity corridors. In Connectivity Conservation; Crooks, K.R., Sanjayan, M., Eds.; Cambridge University Press: Cambridge, UK, 2006; pp. 620-648.

28. Clucas, B.; McHugh, K.; Caro, T. Flagship species on covers of US conservation and nature magazines. Biodivers. Conserv. 2008, 17, 1517. [CrossRef]

29. Veríssimo, D.; Fraser, I.; Groombridge, J.; Bristol, R.; MacMillan, D.C. Birds as tourism flagship species: A case study of tropical islands. Anim. Conserv. 2009, 12, 549-558. [CrossRef]

30. Devictor, V.; Julliard, R.; Clavel, J.; Jiguet, F.; Lee, A.; Couvet, D. Functional biotic homogenization of bird communities in disturbed landscapes. Glob. Ecol. Biogeogr. 2008, 17, 252-261. [CrossRef]

31. Pellissier, V.; Cohen, M.; Boulay, A.; Clergeau, P. Birds are also sensitive to landscape composition and configuration within the city centre. Landsc. Urban Plan. 2012, 104, 181-188. [CrossRef]

32. Xu, X.; Xie, Y.; Qi, K.; Luo, Z.; Wang, X. Detecting the response of bird communities and biodiversity to habitat loss and fragmentation due to urbanization. Sci. Total. Environ. 2018, 624, 1561-1576. [CrossRef] [PubMed]

33. McKinney, M.L. Urbanization as a major cause of biotic homogenization. Biol. Conserv. 2006, 127, 247-260. [CrossRef]

34. Minor, E.; Urban, D. Forest bird communities across a gradient of urban development. Urban Ecosyst. 2010, 13, 51-71. [CrossRef]

35. Fernández-Juricic, E. Can human disturbance promote nestedness? A case study with breeding birds in urban habitat fragments. Oecologia 2002, 131, 269-278. [CrossRef]

36. González-Oreja, J.A.; Hernández-Santín, L.; Bonache-Regidor, C.; Buzo-Franco, D. Can human disturbance promote nestedness? Songbirds and noise in urban parks as a case study. Landsc. Urban Plan. 2012, 104, 9-18. [CrossRef]

37. Laiolo, P. Spatial and Seasonal Patterns of Bird Communities in Italian Agroecosystems. Conserv. Biol. 2004, 1547-1556. [CrossRef]

38. Valente, J.J.; Betts, M.G. Response to fragmentation by avian communities is mediated by species traits. Divers. Distrib. 2019, 25, 48-60. [CrossRef]

39. Bregman, T.P.; Şekercioğlu, C.H.; Tobias, J.A. Global patterns and predictors of bird species responses to forest fragmentation: Implications for ecosystem function and conservation. Biol. Conserv. 2014, 169, 372-383. [CrossRef]

40. Huhta, E.; Mappes, T.; Jokimäki, J. Predation on artificial ground nests in relation to forest fragmentation, agricultural land and habitat structure. Ecography 1996, 19, 85-91. [CrossRef]

41. Hartley, M.J.; Hunter, M.L., Jr. A meta-analysis of forest cover, edge effects, and artificial nest predation rates. Conserv. Biol. 1998, 12, 465-469. [CrossRef]

42. Opdam, P. Metapopulation theory and habitat fragmentation: A review of Holarctic breeding bird studies. Landsc. Ecol. 1991, 5, 93-106. [CrossRef]

43. Schlesinger, M.D.; Manley, P.N.; Holyoak, M. Distinguishing stressors acting on land bird communities in an urbanizing environment. Ecology 2008, 89, 2302-2314. [CrossRef] [PubMed]

44. Kang, W.; Minor, E.S.; Park, C.-R.; Lee, D. Effects of habitat structure, human disturbance, and habitat connectivity on urban forest bird communities. Urban Ecosyst. 2015, 18, 857-870. [CrossRef]

45. Gilbert-Norton, L.; Wilson, R.; Stevens, J.R.; Beard, K.H. A Meta-Analytic Review of Corridor Effectiveness. Conserv. Biol. 2010, 24, 660-668. [CrossRef] [PubMed]

46. Shanahan, D.F.; Miller, C.; Possingham, H.P.; Fuller, R.A. The influence of patch area and connectivity on avian communities in urban revegetation. Biol. Conserv. 2011, 144, 722-729. [CrossRef]

47. Brotons, L.; Herrando, S. Factors affecting bird communities in fragments of secondary pine forests in the north-western Mediterranean basin. Acta Oecol. 2001, 22, 21-31. [CrossRef] 
48. Mönkkönen, M.; Rajasärkkä, A.; Lampila, P. Isolation, patch size and matrix effects on bird assemblages in forest reserves. Biodivers. Conserv. 2014, 23, 3287-3300. [CrossRef]

49. Chalfoun, A.D.; Thompson, F.R.; Ratnaswamy, M.J. Nest predators and fragmentation: A review and meta-analysis. Conserv. Biol. 2002, 16, 306-318. [CrossRef]

50. Tellería, J.L. Manual Para el Censo de Los Vertebrados Terrestres; Editorial Raíces: Madrid, Spain, 1986.

51. Lee, M.B.; Carroll, J.P. Relative importance of local and landscape variables on site occupancy by avian species in a pine forest, urban, and agriculture matrix. For. Ecol. Manag. 2014, 320, 161-170. [CrossRef]

52. PNOA (National Plan for Aerial Orthophotography) IGN. 2020. Available online: https://pnoa.ign.es/ (accessed on 9 September 2021).

53. IDEM (Infrastructure of Spatial Data of Madrid region). Land use and vegetation map of Madrid Region. Regional Government of Madrid. 2018. Available online: https://idem.madrid.org/visor/ (accessed on 4 December 2020).

54. ESRI. ArcGIS 10.7.1: Geographical Information System; ESRI: West Redlands, CA, USA, 2019.

55. JRC 2021 NED-Nestedness for dummies. Joint Research Centre. Available online: https:/ / ecosoft.alwaysdata.net/ (accessed on 9 September 2021).

56. Ulrich, W.; Almeida-Neto, M.; Gotelli, N.J. A consumer's guide to nestedness analysis. Oikos 2009, 118, 3-17. [CrossRef]

57. Mac Nally, R.; Duncan, R.P.; Thomson, J.R.; Yen, J.D.L. Model selection using information criteria, but is the "best" model any good? J. Appl. Ecol. 2018, 55, 1441-1444. [CrossRef]

58. StatSoft Inc. STATISTICA (Data Analysis Software System), Version 8.0; StatSoft Inc.: Tulsa, OK, USA, 2007.

59. Wilson, D.S. Complex interactions in metacommunities, with implications for biodiversity and higher levels of selection. Ecology 1992, 73, 1984-2000. [CrossRef]

60. Hanski, I. Metapopulation Ecology; Oxford University Press: Oxford, United Kingdom, 1999.

61. Mouquet, N.; Loreau, M. Community patterns in source-sink metacommunities. Am. Nat. 2003, 162, 544-557. [CrossRef] [PubMed]

62. Leibold, M.A.; Holyoak, M.; Mouquet, N.; Amarasekare, P.; Chase, J.M.; Hoopes, M.F.; Holt, R.D.; Shurin, J.B.; Law, R.; Tilman, D.; et al. The metacommunity concept: A framework for multi-scale community ecology. Ecol. Lett. 2004, 7, 601-613. [CrossRef]

63. Lussier, S.M.; Enser, R.W.; Dasilva, S.N.; Charpentier, M. Effects of habitat disturbance from residential development on breeding bird communities in riparian corridors. Environ. Manag. 2006, 38, 504-521. [CrossRef]

64. Santos, T.; Tellería, J.L.; Carbonell, R. Bird conservation in fragmented Mediterranean forests of Spain: Effects of geographical location, habitat and landscape degradation. Biol. Conserv. 2002, 105, 113-125. [CrossRef]

65. Doherty, P.F.; Grubb, T.C. Survivorship of permanent-resident birds in a fragmented forested landscape. Ecology 2002, 83, 844-857. [CrossRef]

66. IUCN 2021. The IUCN Red List of Threatened Species; Version 2021-1; International Union for Conservation of Nature and Natural Resources: Gland, Switzerland, 2021; ISSN 2307-8235. Available online: https:/ / www.iucnredlist.org (accessed on 9 September 2021)ISSN 2307-8235.

67. BirdLife International. Aquila adalberti; The IUCN Red List of Threatened Species 2019: E.T22696042A152593918; BirdLife International: Cambridge, UK, 2019. [CrossRef]

68. Herrera, A. Análisis del Carácter de las Vías Pecuarias Como Refugio del Conejo (Oryctolagus cuniculus, L. 1758) en el Centro Peninsular. Master's Thesis, Universidad Autónoma de Madrid, Madrid, Spain, 2021.

69. Chamberlain, D.E.; Toms, M.P.; McHarg, R.C.; Banks, A.N. House sparrow (Passer domesticus) habitat use in urbanized landscapes. J. Ornithol. 2007, 148, 453-462. [CrossRef]

70. De Laet, J.; Summers-Smith, J.D. The status of the urban house sparrow Passer domesticus in north-western Europe: A review. J. Ornithol. 2007, 148 (Suppl. 2), S275-S278. [CrossRef]

71. Shaw, L.M.; Chamberalin, D.; Evans, M. The House Sparrow Passer domesticus in urban areas: Reviewing a possible link between post-decline distribution and human socieoeconomic status. J. Ornithol. 2008, 149, 293-299. [CrossRef]

72. Robillard, A.; Garant, D.; Be'lisle, M. The Swallow and the Sparrow: How agricultural intensification affects abundance, nest site selection and competitive interactions. Landsc. Ecol. 2013, 28, 201-215. [CrossRef]

73. Rottenborn, S.C. Predicting the impacts of urbanization on riparian bird communities. Biol. Conserv. 1999, 88, 289-299. [CrossRef]

74. Benítez-López, A.; Alkemade, R.; Verweij, P.A. The impacts of roads and other infrastructure on mammal and bird populations: A meta-analysis. Biol. Conserv. 2010, 143, 1307-1316. [CrossRef]

75. Halfwerk, W.; Holleman, L.J.M.; Lessells, C.M.; Slabbekoorn, H. Negative impact of traffic noise on avian reproductive success. J. Appl. Ecol. 2011, 48, 210-219. [CrossRef]

76. Buxton, R.T.; McKenna, M.F.; Mennitt, D.; Fristrup, K.; Crooks, K.; Angeloni, L.; Wittemyer, G. Noise pollution is pervasive in U.S. protected areas. Science 2017, 356, 531-533. [CrossRef] [PubMed]

77. Summers, P.D.; Cunnington, G.M.; Fahrig, L. Are the negative effects of roads on breeding birds caused by traffic noise? J. Appl. Ecol. 2011, 48, 1527-1534. [CrossRef]

78. Francis, C.D.; Ortega, C.P.; Cruz, A. Noise pollution changes avian communities and species interactions. Curr. Biol. 2009, 19, 1415-1419. [CrossRef] [PubMed]

79. Gómez-Limón, J.; De Lucío Fernández, J.V. Changes in use and landscape preferences on the agricultural-livestock landscapes of the central Iberian Peninsula (Madrid, Spain). Landsc. Urban Plan. 1999, 44, 165-175. [CrossRef] 
80. Neuschulz, L.; Brown, M.; Farwig, N. Frequent bird movements across a highly fragmented landscape: The role of species traits and forest matrix. Anim. Conserv. 2013, 16, 170-179. [CrossRef]

81. Taylor, J.J.; Lepczyk, C.A.; Brown, D.G. Patch and matrix level influences on forest birds at the rural-urban interface. Landsc. Ecol. 2016, 31, 1005-1020. [CrossRef]

82. Traba, J.; de la Morena, E.L.G.; Morales, M.B.; Suárez, F. Determining high value areas for steppe birds in Spain: Hot spots, complementarity and the efficiency of protected areas. Biodivers. Conserv. 2007, 16, 3255-3275. [CrossRef]

83. Villard, M.A.; Trzcinski, M.K.; Merriam, G. Fragmentation effects on forest birds: Relative influence of woodland cover and configuration on landscape occupancy. Conserv. Biol. 1999, 13, 774-783. [CrossRef]

84. Dakos, V.; Bascompte, J. Critical slowing down as early warning for the onset of collapse in mutualistic communities. Proc. Natl. Acad. Sci. USA 2014, 11, 17546-17551. [CrossRef] [PubMed]

85. Verboom, J.; Schotman, A.; Opdam, P.; Metz, J.A.J. European Nuthatch Metapopulations in a Fragmented Agricultural Landscape. Oikos 1991, 61, 149-156. [CrossRef]

86. Van der Sluis, T.; Schmidt, A.M. E-BIND Handbook (Part B): Scientific Support for Successful Implementation of the Natura 2000 network; Wageningen Environmental Research/Ecologic Institute/Milieu Ltd.: Wageningen, The Netherlands, 2021.

87. Donald, P.F.; Green, R.E.; Heath, M.F. Agricultural intensification and the collapse of Europe's farmland bird populations. Proc. R. Soc. Lond. B Biol. Sci. 2001, 268, 25-29. [CrossRef] [PubMed]

88. Manzano, P.; Casas, R. Past, present and future of Trashumancia in Spain: Nomadism in a developed country. Pract. Action Publ. 2010. [CrossRef]

89. Miller, S.G.; Knight, R.L.; Miller, C.K. Influence of recreational trails on breeding bird communities. Ecol. Appl. 1998, 8, 162-169. [CrossRef]

90. Rochelle, S.; Pickering, J.C.; Castley, G. A review of the impacts of nature based recreation on birds. J. Environ. Manag. 2011, 92, 2287-2294. [CrossRef] 